\title{
THE EXPANDING CIRCLE OF EXACTIONS: FROM DEDICATION TO LINKAGE
}

\author{
Donald L. ConNors* \\ and Michael E. High†
}

I

\section{INTRODUCTION}

Many municipalities are currently experiencing a capital financing crisis fueled by cutbacks in federal aid, decreases in state and municipal taxes, and, frequently, an expanding population base. These developments have forced municipalities to search for innovative methods of financing improvements to infrastructure items such as sewer and water lines, roads and sidewalks, and new or expanded recreational and educational facilities.

Exactions have provided municipalities with one particularly helpful method of financing for these kinds of improvements. They permit municipalities to transfer the financial burden associated with growth and development onto the parties responsible for such growth: the developers and residents of new developments. In the past decade, municipalities have expanded the use of exactions as a financing mechanism beyond the more traditional method of dedication of lands within a subdivision. These new financing schemes include in-lieu fees, impact fees, and, most recently, linkage. This expansion of the exaction concept has eased the financial crisis of municipalities, but it has also raised a plethora of legal hurdles that municipalities must now clear if exactions are to provide a reliable source of funds in the future.

This article reviews the various forms of exactions and the concomitant legal issues raised by the expansion of the exaction concept. It offers a model of legislation that would best insulate a municipal ordinance from invalidation, and thereby delineates a legislative scheme upon which municipalities in need of a reliable source of funding may rely. The discussion concludes with an analysis of linkage and a critical review of a recent amendment to the city of Boston zoning ordinance that implements linkage. The assessment of the Boston ordinance reveals that, in its current formulation, it is susceptible to invalidation for reasons that go to the heart of the controversy over exactions.

Copyright @ 1987 by Law and Contemporary Problems

* Lead Partner, Land Use, Land Development, and Environmental Group, Choate, Hall \& Stewart, Boston, Massachusetts; Member, American Institute of Certified Planners.

$\dagger$ Associate, Pierce Atwood, Scribner, Allen, Smith \& Lancaster, Portland, Maine. 
II

\section{Discussion}

\section{A. Types of Exactions}

An exaction is essentially a condition of carrying forward a project in the form of a contribution made by a developer to a municipality. ${ }^{1}$ The payment is ordinarily a condition precedent to the issuance of a special permit, a conditional use permit, a subdivision approval, or an amendment to a zoning map. The nature of the developer's contribution determines the type of exaction. The most common and least controversial type of exaction is an intradevelopmental dedication of land for streets, sidewalks, water and sewer lines, and, more recently, land for recreational or educational purposes. ${ }^{2}$ Municipalities also frequently require developers to construct specific improvements such as sidewalks and streets in addition to dedicating the lands for these uses. Although susceptible to legal challenge,$^{3}$ courts are least likely to invalidate this type of exaction. Municipalities clearly have legitimate general health, safety, and welfare interests in assuring adequate ingress and egress from a new development, and such improvements are a necessary adjunct to a municipality's zoning or subdivision control power. Furthermore, this type of intradevelopmental exaction scheme is fair because it places the costs of growth squarely upon the shoulders of those who created the need and upon those who will directly benefit from the product of the exaction. Municipalities can safely and confidently rely on intradevelopmental dedications of land, ${ }^{4}$ because this type of dedication has the appearance of a reasonable exercise of police power concerning land use regulation.

1. See Diamond, The San Francisco Office/Housing Program: Social Policy Underwritten by Private Enterprise, 7 Harv. Envtr. L. Rev. 449, 455 (1983); Comment, Subdivision Exactions: The Constitutional Issues, The Judicial Response, and the Pennsylvania Situation, 19 VILL. L. Rev. 782, 784 (1974). For an indepth discussion of the constitutional issues raised by exaction schemes, see Heyman \& Gilhool, The Constitutionality of Imposing Increased Community Costs on New Suburban Residents through Subdivision Exactions, 73 YaLE L.J. 1119 (1964).

2. The dedication of land for park purposes within a subdivision was first considered and affirmed in In re Lake Secor Dev. Co., 141 Misc. 913, 252 N.Y.S. 809 (Sup. Ct. 1931). Since then, courts have not had particular difficulty with the notion of intradevelopmental exactions. See Pavelko, Subdivision Exactions: A Review of Judicial Standards, 25 J. URB. Const. L. 269, $273-76$ (1983); see also Trent Meredith, Inc. v. City of Oxnard, 114 Cal. App. 3d 317, 324-28, 170 Cal. Rptr. 685, 689-91 (1981) (payment of fees or dedication of lands for schools is proper police power regulation); Krughoff v. City of Naperville, 41 Ill. App. 3d 334, 338, 354 N.E.2d 489, 494 (1976) (municipalities are vitally interested in adequate provision of educational and recreational resources), aff $d, 68 \mathrm{Ill} .2 \mathrm{~d}$ 352, 369 N.E.2d 892 (1977).

3. One would challenge a dedication requirement on the same basis as any other exaction, raising the constitutional issues associated with a taking of property for "what might otherwise have been characterized as municipal functions." Comment, supra note 1, at 785 . Acute legal problems may arise where the dedication requirement is stated as a percentage of the area of land developed. See J.E.D. Assocs. v. Town of Atkinson, 121 N.H. 581, 583-85, 432 A.2d 12, 14-15 (1981); Frank Ansuini, Inc. v. City of Cranston, 107 R.I. 63, 71-72, 264 A.2d 910, 914-15 (1970).

4. Although municipalities might well rest content with any source of funding, this discussion focuses upon those sources of funds that may provide a reliable or steady source of funds. 
Dedication, however, is a very limited method of land use regulation and simply cannot resolve the complex municipal problems associated with rapid growth. Smaller developments, for example, may not have the requisite space available for a dedication of land for recreational or educational purposes. Nonetheless, a series of such smaller developments clearly will create a need for parks and schools. Unless the municipality has access to an alternative type of exaction, it could find itself supplying newcomers with parks and schools from the general revenues of the municipality-a situation that passes the direct costs of growth on to all residents. The in-lieu fee has emerged to manage such a situation, and has become an important and reliable method of municipal financing of improvements. ${ }^{5}$ In those cases where the dedication of land or construction of improvements within the development site is not appropriate, many municipal ordinances now provide that developers may proceed with construction if they pay a fee in lieu of the land dedication. The municipality may then collect and pool these fees. A properly drafted ordinance must specify that the use of the fees is limited to the eventual acquisition of a park or construction of a school that will primarily, although not exclusively, benefit the residents of the new development.

In-lieu fees have thus emerged as an outgrowth of dedication. With proper enabling legislation and an appropriately delimited use of proceeds, courts will very likely conclude that in-lieu fees are as uncontroversial a method of land use regulation as intradevelopmental dedication. In-lieu fees have a narrow focus, however: these fees are conceptually tied to the same type of use ordinarily associated with land dedication. Those municipalities that have experienced rapid growth confront the problem that growth strains and frequently requires the expansion or reconstruction of the capital infrastructure of the municipality. Although a municipality's capital infrastructure is outside the scope of the new development, the condition of that infrastructure may be vital to the success of a development. For example, a municipality may need a water treatment plant or require a new or improved road system. The municipality must confront the issue of the means to pay for these improvements. Traditional in-lieu fees, of course, simply do not reach these extradevelopmental ramifications of growth. Lacking an alternative source of funding, municipalities may be confronted with the prospect of constructing new or rehabilitating existing infrastructure items from their general revenues because of needs created by new developments. Once again, municipalities have looked for a method that would require the creators of the need for improvements to bear the costs associated with growth. Impact fees, "charges levied by local governments against new development in order to generate revenue for capital funding necessitated by

5. See J. Juergensmeyer, Funding Infrastructure: Paying the Costs of Growth Through Impact Fees and Other Land Regulation Charges 2-3 (1985); see also Jacobsen \& Redding, Making Development Pay Its Way, 55 N.C.L. Rev. 407, 407 (1977); Juergensmeyer \& Blake, Impact Fees: An Answer to Local Governments' Capital Funding Dilemma, 9 FlA. ST. U.L. Rev. 415,418 (1981). 
the new development,"'6 have emerged as one solution. Although more susceptible to successful legal challenge by developers, the impact fee has served very well as a mechanism for municipalities wishing to finance the extradevelopmental costs of growth. If equitably implemented, that is, if proportionate payments and empirical data tie cost increases to new development, such fees also have the indicia of a legitimate method of land use regulation.

The exaction mechanisms discussed thus far bear a family resemblance to one another and can be placed on a continuum. It is clear that suburban growth first had immediate and then broader consequences, and exactions expanded to meet these consequences. One can understand that municipalities, always strapped for funds and yet bound to provide services, would respond with a type of exaction that would manage the expanding consequences of growth. The most recent development in this area of the law, linkage, seems to represent a movement off this continuum. The family resemblance to traditional exaction schemes, although present, is faint. Linkage requires developers to contribute toward, or construct housing for, those who will purportedly come to the city because of the new construction. The contribution may take the form of a condition precedent for special permit approval. Linkage thus extends the exaction notion to an unprecedented area-the housing market. Unlike the other exaction schemes and despite the veneer, it appears that linkage is less a method of making development pay its way ${ }^{7}$ than a way of providing "a steady local foundation for ... housing development that is not subject to the vagaries of national policy or the local budget process." 8 In other words, linkage functions primarily, not incidentally, as a means of implementing social policy. In this sense, linkage is more susceptible to constitutional challenges because it possesses less of the appearance of reasonability and fairness than do the other types of exaction.

With this conceptual framework established, this article will now discuss the legal issues raised by the various exaction regimes. In particular, it will focus on the type of municipal ordinance that will both raise funds and yet withstand legal challenge. This analysis is important in an age of declining federal involvement and lower state and municipal real estate tax revenues, because municipalities need a steady reservoir of funding in order to pay for needed improvements.

6. J. Juergensmeyer, supra note 5, at 2; see also Jacobsen and Redding, supra note 5, at 408-11.

7. The basis of any claim arguing in favor of the reasonability of legitimate land use regulations is the notion that a development should pay the municipal costs created by it. This notion also justifies the claim by municipalities that the imposition of such exaction fees is fundamentally fair. See Associated Home Builders v. City of Walnut Creek, 4 Cal. 3d 633, 637-47, 484 P.2d 606, 610-17, 94 Cal. Rptr. 630, 634-41, appeal dismissed, 404 U.S. 878 (1971); Contractors \& Builders Ass'n v. City of Dunedin, 329 So. 2d 314, 318-21 (Fla. 1976), reconsidered on appeal from unpublished remand, 358 So. 2d 846 (Fla. Dist. Ct. App. 1978), cert. denied, 370 So. 2d 458, cert. denied, 444 U.S. 867 (1979).

8. Tegeler, Developer Payments and Downtown Housing Trust Funds, 18 Clearinghouse REv. 679, 680 (1984). 


\section{B. Legal Issues: The Importance of Enabling Legislation}

The initial and perhaps critical hurdle confronting any municipal exaction scheme is adequate state enabling legislation. On numerous occasions courts have invalidated municipal ordinances not expressly authorized by state constitution or statute. ${ }^{9}$ City of Montgomery $v$. Crossroads Land Co. ${ }^{10}$ illustrates the potential problem nicely. In City of Montgomery, a state statute authorized town planning commissions "to adopt regulations providing 'for adequate and convenient open spaces for .. . recreation." 11 Pursuant to this legislation, the city implemented subdivision regulations requiring subdivision developers to dedicate .18 acres per dwelling unit constructed, or to donate an in-lieu fee to a fund held for the acquisition of public parks and playgrounds.

The court perfunctorily invalidated the ordinance, noting only that the enabling legislation did not specifically authorize the fee payment in lieu of the land dedication as a condition of approval of a subdivision plat. ${ }^{12}$ Absent such specific legislative authorization, the court concluded that "the City of Montgomery has no implied power to require the payment of a fee in lieu of dedication of land for public parks."'13

City of Montgomery serves as a lesson to the state legislature: in establishing exaction schemes it should make grants broad, yet specific. The grant should authorize municipalities to provide for the full range of exactions and then leave them with the discretion to determine the type of exaction appropriate in a particular case.

Such legislation is a heuristic device rather than a reality, however. In fact, in most cases there is no express legislation at all. Municipalities simply enact ordinances authorizing a range of exactions in reliance upon an implied power pursuant to, for example, a home rule amendment. Although courts have upheld exactions under home rule authority, ${ }^{14}$ such an implied power remains susceptible to too many successful legal challenges. In Middlesex $\mathcal{E}^{2}$ Boston Street Railway v. Board of Aldermen, ${ }^{15}$ for example, the Supreme Judicial Court of Massachusetts invalidated a special permit condition requiring that a developer lease five of his fifty-four units to the city housing authority, despite the existence of a home rule amendment. The developer in Middlesex required a special permit to construct his project, and the Newton zoning ordinance authorized the Board of Aldermen to grant such permits. The court acknowledged that the Board could grant the developer a special permit, but

9. See, e.g., Kamhi v. Planning Bd., 59 N.Y.2d 385, 389-91, 452 N.E.2d 1193, 1194-95, 465 N.Y.S.2d 865, 866-67 (1983); Riegert Apartments Corp. v. Planning Bd., 57 N.Y.2d 206, 208-12, 441 N.E.2d 1076, 1077-79, 455 N.Y.S.2d 558, 559-61 (1982) (town derives its power to regulate land uses from legislature).

10. 355 So. 2d 363 (Ala. 1978).

11. Id. at 364 .

12. Id.

13. Id. at 365 .

14. See, e.g., Coulter v. City of Rawlins, 662 P.2d 888, 894-95 (Wyo. 1983) (municipal fee for connecting to municipal water and sewer lines affirmed as implied from home rule authority).

15. 371 Mass. 849 , 359 N.E.2d 1279 (1977). 
ruled that it could not extract the aforementioned exaction. ${ }^{16}$ The court explicitly rejected the Board's purported reliance upon the Massachusetts Home Rule Amendment ${ }^{17}$ and noted that " $[t]$ here is no language anywhere in the [state] statute or in the Newton zoning ordinance which expressly authorized the Board to impose [the condition]."18 Although home rule is the best option available in many circumstances, many municipalities still view it as susceptible to scrutiny and invalidation by more conservative courts.

The municipality must jump a second hurdle in order to avoid a judicial conclusion that the particular exaction is a tax. Enabling legislation often plays a critical role in this determination. Enabling legislation is so critical because, once a court attaches the label "taxation" to the ordinance, the court will invalidate it unless the municipality has received an express delegation of taxing authority. ${ }^{19}$ Such an express delegation rarely exists, thus the label becomes, as the commentators have noted, outcome determinative. ${ }^{20}$

Home Builders Association v. Riddel ${ }^{21}$ illustrates the dilemma. In Riddel, the municipal ordinance required that developers pay a set fee for each unit of residential construction. The fees would be collected, pooled, and later used to provide parks and recreational facilities for the community. The Riddel court first noted that municipalities have the power to tax "only to the extent to which it is clearly conferred by the charter or state statutes." 22 The city charter did grant it "all powers possible for a city under the constitution and laws of the State of Arizona." 23 Despite such a broad grant of authority, the court refused to imply the grant of a tax collecting power. It invalidated the ordinance as an illicit tax because the charter did not "specifically authorize"24 the tax found in the municipal ordinance.

A recent Florida case, Town of Longboat Key $v$. Lands End, Ltd., ${ }^{25}$ illuminates a related point. In Lands End, an ordinance required developers to dedicate land for, or to pay a fee to acquire, land for parks and open spaces. Any fees collected would be "expended solely for the acquisition, improvement,

16. Id. at 855,359 N.E. $2 \mathrm{~d}$ at 1282.

17. Id. at 856,359 N.E.2d at 1283 . Under home rule authority, a municipality may enact zoning regulations for the health and general welfare of a municipality. See MAss. Const. amended art. II, $\S 1$; Mass. AnN. Laws ch. 43B, §§ 1-20 (Law. Co-op. 1986); see also Marshfield Family Skateland v. Town of Marshfield, 389 Mass. 436, 440-41, 446, 450 N.E.2d 605, 608, 611 (1983); Board of Appeals v. Housing Appeals Comm., 363 Mass. 339, 358-60, 294 N.E.2d 393, 409-10 (1973).

18. 371 Mass. at 856,359 N.E.2d at 1283 (emphasis added). The court did note that "[t]here is no constitutional obstacle to the accomplishment of the ends contemplated by the board ... [the ends beingl the provision of adequate housing for low income and elderly persons." Id. at 857, 359 N.E.2d at 1284 .

19. See Hillis Homes, Inc. v. Snohomish County, 97 Wash. 2d 804, 809, 650 P.2d 193, 195 (1982) (county must have express power to tax developers) (superseded by WASH. Rev. CodE ANN. $\S 82.02 .020$ (Supp. 1987)).

20. See J. JUERGENSMEYER, supra note 5, at 4-7; Juergensmeyer \& Blake, supra note 5, at 422-27.

21. 109 Ariz. 404, 510 P.2d 376 (1973).

22. Id. at 406, 510 P.2d at 378 (quoting Phoenix v. Arizona Sash, Door \& Glass Co., 80 Ariz. 100, 102-03, 293 P.2d 438, 439, modified, 80 Ariz. 239, 295 P.2d 854 (1956)).

23. $I d$.

24. Id. at 407,510 P.2d at 379 . The court also noted that "the primary effect [of the regulation] is to benefit the public at large." Id.

25. 433 So. 2d 574 (Fla. Dist. Ct. App. 1983). 
expansion of Town Parks, open space land and land for specified Town purposes and facilities required as capital improvements ...."26 The court held that the ordinance imposed an invalid tax because "there [was] no real guarantee that the funds collected will actually be used to promote the development and acquisition of open space and park land, the need for which is generated by the new development."27

A review of the cases and commentary on taxation versus regulation adds few conceptual insights into the nature of either legal notion. Examination of the wreckage of invalidated ordinances, however, makes clear that an ordinance is more likely to attract the regulation label and thereby to withstand a legal challenge if: (a) there is clear enabling legislation authorizing the imposition of a fee; and (b) the fees collected are marked for purposes that will primarily benefit the residents of the new development. Conceptual tidiness aside, these factors create the appearance of a police power regulation and maximize the likelihood that the ordinance is valid.

\section{Standards of Judicial Review: A Proposed Model of Legislation}

Once a municipality establishes that its exaction scheme is authorized by some express or implied state authority and that any fees paid pursuant thereto do not constitute a tax, the legality of the scheme still may not withstand attack on several ordinarily constitutional grounds. The courts might invalidate an exaction program as violative of due process or equal protection, ${ }^{28}$ or as an unconstitutional taking. The fundamental source of authority for any exaction scheme is the police power, and the legitimacy of exactions is therefore ordinarily determined with reference to a reasonableness standard. It is therefore necessary to focus on the various standards of reasonableness that courts have formulated when construing the validity of exactions.

A court will usually review the reasonability of an exaction under one of three tests: (1) the "strict need or direct benefit" test; (2) the "specifically and uniquely attributable" test; or (3) the "rational nexus" test. ${ }^{29}$ Gulest Associates

26. Id. at 575 .

27. Id. at 576; cf. Hollywood, Inc. v. Broward County, 431 So. 2d 606, 614 (Fla. Dist. Ct. App. 1983) (exaction should "offset, but not exceed, reasonable needs sufficiently attributable to the new subdivision residents and . . . the funds collected [should be] adequately earmarked for the acquisition of capital assets that will sufficiently benefit those new residents."); Coates v. Planning Bd., 58 N.Y.2d 800, 802, 445 N.E.2d 642, 643, 459 N.Y.S.2d 259, 260 (1983) (fees imposed that cover municipality's costs are not arbitrary and capricious, especially "since the village code requires the unexpended portions of such fees be refunded to petitioners.").

28. The equal protection claims will not be discussed in any detail because an exaction program need only avoid the label "palpably arbitrary" in order to survive an equal protection challenge. See, e.g., Norsco Enters. v. City of Fremont, 54 Cal. App. 3d 488, 498, 126 Cal. Rptr. 659, 665 (1976).

29. Municipal ordinances requiring dedication also have been upheld on various other theories. See Note, Mandatory Dedication of Land by Land Developers, 26 U. FLA. L. REv. 41 (1973); see also Pavelko, supra note 2, at 283 (privilege test). 
v. Town of Newburgh ${ }^{30}$ best illustrates the direct benefit test. In Gulest, a municipal ordinance conditioned approval of subdivision plats on the payment of fees to the Town Board for use in the improvement or acquisition of neighborhood parks and playgrounds. There was no requirement that the town use the money collected in a way that would benefit the residents of the subdivision. Rather, the exaction funds passed into general revenues and were available for general playground and recreational purposes. The court held that the ordinance constituted a taking without due process of law, as well as a violation of the equal protection clause, precisely because the exactions were available for general recreational revenue purposes. ${ }^{31}$ In other words, residents of the subdivision who ultimately paid the exaction received no direct benefits from their payments.

The now famous Pioneer Trust $\mathcal{G}^{2}$ Savings Bank $v$. Village of Mount Prospect ${ }^{32}$ first articulated the specifically and uniquely attributable test and remains an excellent illustration. Pioneer was an "easy case." It involved an ordinance requiring the intradevelopmental dedication of land for schools. The specified acreage of land to be dedicated was computed on the basis of the number of residential lots constructed. The stipulated facts indicated, however, that the town's school facilities had been utilized to capacity prior to the proposed development. The need for additional schools was therefore not specifically and uniquely attributable to the development. ${ }^{33}$ The court determined that, on the basis of the stipulated facts, the dedication requirement constituted a forbidden "confiscation of private property in contravention of the constitutional prohibitions rather than reasonable regulation under the police power." 34

As the commentators have noted, these tests establish criteria with which a municipality may be unable to demonstrate compliance once population growth has started to strain a municipality's infrastructure. ${ }^{35}$ In many instances, the strain on infrastructure results from the cumulative effect of several developments in the recent past rather than the simple presence of a single development. A municipality may therefore find it impossible to demonstrate conclusively that the proceeds of an exaction will directly benefit a particular contributor or that the needs for new or expanded infrastructure are directly attributable to a development. Because of these difficulties, most courts now adhere to a third test: the rational nexus test, first articulated in

30. 25 Misc. 2d 1004, 209 N.Y.S.2d 729 (Sup. Ct. 1960), aff'd, 15 A.D.2d 815, 225 N.Y.S.2d 538 (1962). Gulest was overruled with respect to its holding concerning the vagueness of the Newburgh statute in Jenad, Inc. v. Village of Scarsdale, 18 N.Y.2d 78, 218 N.E.2d 673, 271 N.Y.S.2d 955 (1966).

31. 25 Misc. $2 d$ at $1007-08,209$ N.Y.S.2d at 732-33.

32. 22 Ill. 2d 375,176 N.E.2d 799 (1961).

33. Id. at 381,176 N.E.2d at 802 . The court observed that "the school problem which allegedly exists here is one which the subdivider should not be obliged to pay the total cost of remedying." Id. (emphasis added). Presumably, a proportionate contribution would not have constituted a taking.

34. Id.; see also Krughoff v. City of Naperville, 41 Ill. App. 3d 334, 354 N.E.2d 489 (1976), aff'd, 68 Ill. 2d 352, 369 N.E.2d 892 (1977).

35. See Pavelko, supra note 2, at 291. See generally J. Juergensmeyer, supra note 5. 
Jordan v. Village of Menomonee Falls. ${ }^{36}$ Jordan concerned in-lieu fees or dedication requirements for extradevelopmental educational and recreational purposes. The court acknowledged that the municipal needs were not directly attributable to each developer and his development, but held that the test should focus on whether the need for infrastructure is sufficiently attributable to the activities of the developer to justify an exaction. Furthermore, the court did not require the municipality to prove that the development would be the sole beneficiary of the facility constructed or repaired with the extradevelopmental fee. The municipality had to show only that the residents of the development would receive benefits in reasonable proportion to their contribution to the facility's construction. ${ }^{37}$

The rational nexus test provides the best framework for addressing the validity of an exaction scheme because it considers the needs of the community and is at the same time fair to the developer. Developments do in fact have significant extradevelopmental impacts on infrastructure. Continued subdivision approvals may stretch a school system or a water and sewage system beyond capacity, requiring a significant expenditure of municipal funds. On the other hand, developers, and ultimately the residents of a development, should not pay for improvements that are not reasonably related to the development's impact on infrastructure and from which the residents will not derive any benefit. The solution, of course, is to tie a developer's contribution to the costs that are reasonably attributable to his development. In summary, a rule of law that expressly addresses the issue whether an exaction is reasonably and proportionally related to need and benefit is clearly the better rule.

This brief review of the principal legal issues confronting municipalities that seek to implement exaction schemes reveals a reasonable course that municipalities can follow. More importantly, the case law indicates that if the municipal ordinance is properly authorized and if the exaction satisfies the appropriate legal standard of reasonableness, municipalities will have a source of funds available for educational and recreational projects as well as infrastructure improvements.

\section{Applying the Proposed Rule: The Linkage Program in Boston}

An important infrastructure problem confronting many municipalities today is a shortage of housing. Linkage programs, which represent the latest development in the expanding circle of exactions, have been used by municipalities to address the housing shortage dilemma. A linkage program attempts to tie large downtown developments to the construction of new housing. The program accomplishes this result by requiring developers either to pay a fee or actually to build such housing as a condition of receiving

36. 28 Wis. $2 \mathrm{~d} 608,137$ N.W.2d 442, appeal dismissed, 385 U.S. 4 (1966).

37. Id. at 617,137 N.W. $2 \mathrm{~d}$ at $447-48$. 
development approval for a proposed project. Simply put, the plan seeks to spread the downtown's prosperity into the neighborhoods.

If legally permissible, municipalities that are experiencing significant commercial development and prosperity, but that also have an older housing stock and a tight housing market, would find linkage schemes particularly attractive. Moreover, the time is right for linkage-cutbacks in federal assistance to low- and moderate-income housing construction as well as taxpayer revolts make linkage a possibly critical source of municipal funding for housing. The linkage ordinance recently enacted by the city of Boston will be used as a focus for discussion of the legal issues raised by a linkage program. ${ }^{38}$

The city of Boston enacted its linkage program in 1983. Prior to the enactment, the city had conducted several planning studies. The Advisory Group report on linkage between downtown development and neighborhood housing revealed that Boston was a prime candidate for linkage. ${ }^{39}$ The study discussed the increasing problems of housing affordability and decreasing public resources available for housing experienced by Boston, and noted the recent rapid and substantial development in the downtown area.40 The Advisory Group also noted that the median income of Boston's population was below that of other cities, and that housing in general, but housing for low- and moderate-income people in particular, was scarce. It concluded that a booming downtown that abutted busted neighborhoods seemed perfectly suited for a linkage program. ${ }^{41}$

The Boston program applies only to substantial projects that are defined as new construction and rehabilitation projects of more than 100,000 square feet. As a prerequisite for granting any conditional use permit or allowing any variance, exception, or amendment to the zoning map, the ordinance requires that developers agree to pay a development impact project exaction of $\$ 5$ per square foot for each square foot over the 100,000 square foot threshold. ${ }^{42}$ The linkage fee is payable in seven equal annual installments with the first installment due upon issuance of the building permit, followed by six payments due annually thereafter. The exactions are paid to a Neighborhood Housing Trust, which administers the funds that are received pursuant to the program. ${ }^{43}$

38. Boston, Mass., Zoning Code art. 26 (1983), amended by Boston, Mass., Zoning Code art. 26A (1986). For an excellent review of the linkage program in San Francisco, see Diamond, supra note 1. At this time several cities are considering implementing linkage programs, including Denver and Seattle. Cambridge, Massachusetts, recently rejected a linkage program.

39. Advisory Group, Linkage Between Downtown Development and Neighborhood Housing: Report to the Mayor 1 (1983) [hereinafter Advisory Group Report]. The group observed that "[a]ffordability of housing is a major problem, particularly for Boston's tenants." Id. at 6 .

40. Id. at 5-7.

41. Id. at 9 .

42. Boston, Mass., Zoning Code art, 26A, § 2(3)(b) (1986).

43. Id. $\S 2(3)$. 
It is not yet clear whether this program will withstand legal challenge. The Suffolk County Superior Court recently held the linkage ordinance invalid in Bonan v. General Hospital Corp. ${ }^{44}$ Although the Massachusetts Supreme Judicial Court subsequently vacated that decision on procedural grounds, ${ }^{45}$ the superior court opinion is instructive because it indicates the probable results of further attacks on the ordinance. In particular, it illustrates the dependence of the outcome upon state statutory and case law.

The superior court judge held that Boston's Zoning Commission (the legislative body having authority to enact zoning ordinances in Boston) is bound by the legislature's delegation of power, and that linkage is not a zoning power authorized expressly or by implication in Boston's special zoning enabling act. ${ }^{46}$ Boston is not subject to the general Massachusetts Zoning Enabling $\mathrm{Act}^{47}$ because, pursuant to a special act of the legislature in 1956, Boston was authorized to establish its own system of zoning regulations. ${ }^{48}$ The superior court judge found that the express grant of powers contained in Boston's special zoning enabling act was limited to typical height, bulk, and density dimensional controls, together with typical use controls. The special act did not, however, expressly contain the power to exact a fee, tax, or in-kind contribution as the linkage ordinance purported to contain. The superior court relied on Middlesex, ${ }^{49}$ in which the supreme judicial court held that there was no express grant of authority for a linkage program under the general Massachusetts Zoning Enabling Act. ${ }^{50}$ At the time of Middlesex, both enabling acts were similar in all material respects. The

44. No. 76438 (Mass. Super. Ct. Mar. 31, 1986) (order granting summary judgment), rev'd sub nom. Bonan v. City of Boston, 398 Mass. 315, 496 N.E.2d 640 (1986). The plaintiffs were Boston residential property owners who opposed an amendment to an existing Planned Development Area (PDA) designation which would have allowed a neighboring hospital to increase the density ratios and size of its facilities. Approval of the amendment required linkage payments which, the plaintiffs alleged, were the city's primary motivation for granting the approval and were exacted under an unauthorized and therefore unlawful scheme.

45. Bonan v. City of Boston, 398 Mass. 315, 496 N.E.2d 640 (1986). The court held that summary judgment against defendants in the superior court had been premature because the defendants had filed no responsive pleadings and there was no agreement as to the facts. Moreover, it held that plaintiffs failed to state an actual controversy entitling them to declaratory relief. Finally, it held that the plaintiffs lacked standing to challenge the validity of the linkage ordinance. See also lodice v. City of Newton, 397 Mass. 329, 491 N.E.2d 618 (1986), an earlier challenge to a $10 \%$ lowincome set-aside requirement enacted by a municipality under the commonwealth's General Zoning Enabling Act, Mass. ANN. Laws ch. 40A (Law. Co-op. 1985). In Iodice, the supreme judicial court also disposed of the case upon a narrow procedural ground, holding that the action was in essence the complaint of a person aggrieved by the decision of a special permit granting authority and, accordingly, must have been brought within the statutorily mandated appeal period of 20 days following the filing of the decision.

46. Bonan, slip. op. at 14-19. The program in San Francisco also suffers from a lack of clear enabling legislation. See Diamond, supra note 1, at 462-66. Diamond recommends, however, that the city adopt the program.

47. Mass. ANN. Laws ch. 40A, §§ 1-17 (Law. Co-op. 1985).

48. 1956 Mass. Acts ch. 665.

49. 371 Mass. 849, 359 N.E.2d 1279 (1977); see supra text accompanying notes 15-18.

50. Id.; see Mass. AnN. Laws ch. 40A, §§ 1-17 (Law. Co-op. 1985). 
superior court thus held that it could "safely conclude" that there was no express authorization for linkage. ${ }^{51}$

The superior court also refused to imply authorization to enact the linkage ordinance. The city argued that Boston's special zoning enabling act authorizes it to regulate land uses in order "to avoid undue concentration of population, to facilitate the adequate provision of transportation, water, sewerage, schools, parks and other public requirements . . . to encourage the most appropriate use of the land throughout the city; and to preserve and increase [the city's] amenities." 52 The court responded that although linkage might bear a substantial relation to these purposes for which the zoning power may be used, the zoning powers delegated for achieving these purposes were limited, and to accept this argument was to fail to distinguish zoning purposes from zoning powers. ${ }^{53}$

The court further observed that three additional considerations reinforced its conclusions regarding the lack of implied authorization: (1) fees are expressly authorized elsewhere in Boston's special zoning enabling act; (2) the linkage payment would, under Massachusetts law, be characterized as a tax, and accordingly could not be authorized except by an express authorization; ${ }^{54}$ and (3) the legislature, after the Middlesex case, had specifically amended the general zoning enabling act to authorize certain linkage provisions, but had not made parallel changes in Boston's special zoning enabling act. ${ }^{55}$

Although this first holding was dispositive, the court went on to address the characterization of the linkage payment as a regulatory fee or a tax. In so doing, the court relied on Emerson College $v$. City of Boston, ${ }^{56}$ a recent Massachusetts decision in which the court analyzed the criteria for distinguishing a regulatory fee from a tax. In Emerson College, the state legislature authorized Boston to impose a fee for augmented fire services availability (AFSA) on "certain buildings that "by reason of their size, type of construction, use and other relevant factors ... require the city to employ additional firefighters, deploy additional equipment and purchase equipment different in kind from that required to provide fire protection for the majority of structures." 57 The city levied a fee that was an exaction aimed at large developments and institutions, and Emerson College challenged the validity of the ordinance authorizing the fee. The supreme judicial court addressed the nature of the monetary exaction and whether the exaction was in fact part

51. Bonan, slip. op. at 16.

52. 1956 Mass. Acts ch. 665, $\S 2$, cited in id. at 17 .

53. Bonan, slip op. at 17-18.

54. See infra text accompanying notes 56-61.

55. Bonan, slip op. at 18-21.

56. 391 Mass. 415, 462 N.E.2d 1098 (1984) (fee for augmented fire services availability, aimed only at large developments and institutions, held an illicit tax when used for maintenance of facilities for general public).

57. Id. at 416, 462 N.E.2d at 1100; see 1982 Mass. Acts ch. 190, $\$ 30$. 
of a scheme to have owners of private property provide a service that is actually a general function of government.

Under the court's analysis, the monetary exaction must be categorized as either a fee or a tax. Fees are either user fees, imposed on a proprietor for instrumentalities used, such as the sewage system, or regulatory fees, founded on the police power to regulate businesses and activities. In either case, however, fees, as opposed to taxes, are charged in exchange for particular governmental services benefiting the payer and "are collected, not to raise revenues but to compensate the governmental entity providing the services for its expenses."58 Finally, fees paid for services should benefit the particular group incurring the expense. The court found that the program was an illicit tax because the AFSA exaction was paid both for possible services and to maintain facilities that were used to provide essential services to the general public. 59

In light of these criteria, the superior court in Bonan concluded that linkage "more closely resembles a tax than a fee" and that "its primary purpose is to raise revenues . . . to be expended for the common good through the construction of low and moderate income housing."60 It held that "the size and revenue raising function of the [linkage payment] warrants that it be considered a tax for purposes of statutory authorization and construction."61

The superior court concluded that whether the linkage payment was a fee or a tax, it was not authorized by statute, and therefore the ordinance was a nullity. The court also invalidated any zoning relief the city had granted to the defendant that was contingent upon the linkage exaction. ${ }^{62}$ The court has thus paved the way for future challenges to Boston's linkage ordinance. Undoubtedly, both the absence of express legislative authorization for linkage and the striking similarity of linkage payments to a source of general revenue will continue to present substantial obstacles for defenders of the ordinance.

Although the supreme judicial court vacated the superior court decision on procedural grounds, the substantive analysis of Bonan and Emerson College continue to be troublesome for municipalities planning to implement linkage. The city of Boston does not collect the linkage fee as compensation for services provided or for the use of its instrumentalities. Instead, it is a source of general funds to solve a perceived social problem: a shortage of affordable housing in Boston. The linkage fees in the Boston Zoning Code bear a striking similarity to a source of general revenue to a city in need rather than a

58. Id. at 425, 462 N.E.2d at 1 105. In Hillis Homes, Inc. v. Snohomish County, the court found that a purported development fee was a tax, the purpose of which was to assist the municipality in realizing a public purpose which required funding. 97 Wash. 2d 804, 650 P.2d 1983 (1982) (superseded by Wash. Rev. Code Ann. $\$ 82.02 .020$ (Supp. 1987)).

59. 391 Mass. at 427,462 N.E.2d at 1106.

60. Bonan v. General Hosp. Corp., No. 76438, slip op. at 20 (Mass. Super. Ct. Mar. 31, 1986) (order granting summary judgment).

61. Id.

62. Id. at 21 . 
fee for services. The AFSA scheme in Emerson College had the effect of requiring property owners to provide a general service ordinarily provided by municipal government. Linkage fees are strikingly similar. They serve as a poor disguise for requiring developers to provide low- and moderate-income housing, ${ }^{63}$ a service that is ordinarily provided by government.

The city may face additional hurdles in future challenges. Even if Boston's linkage exactions are viewed as regulatory fees, they must still pass the reasonability test generally applied to any police power regulation. The amendment justifies the linkage program by reasoning that a commercial development should pay for the housing needs created by the development. ${ }^{64}$ This argument has traditionally been used to justify impact fees: development creates strain on the capital infrastructure of a municipality, now extended to include housing, and such development should pay the costs of repairing, extending, or constructing such infrastructure. The primary problem is that neither the Advisory Group nor the Zoning Commission incorporated adequate empirical findings of fact regarding the impact of commercial development on housing in Boston. It therefore could not tie such findings to the formula used to compute the linkage fee. The lack of findings makes the fee vulnerable to a judicial determination that it is an arbitrary and capricious imposition rather than a reasonable method of land use regulation. The lack of a reasonable connection between commercial development and the housing shortage may cause particular troubles to defenders of the Boston program. The supreme judicial court, in Emerson College, has already noted that fees paid should benefit the group incurring the expense. ${ }^{65}$ The absence of findings of fact on the impact of development, and a corresponding formula, raise serious doubts that the Boston program will withstand further judicial review. ${ }^{66}$

These flaws in the Boston program are peculiar to it. Properly drafted linkage programs that are supported by findings of fact and enacted pursuant to police power authority may still be legally viable. As one commentator has noted, linkage bears some resemblance to inclusionary zoning, a mode of land use regulation that has gained broad public and judicial acceptance. ${ }^{67}$ If a municipality establishes that development causes a shortage of a necessary

63. Diamond, supra note 1, at 462-80, maintains that the San Francisco program is valid under California law. She reaches this conclusion because, under California law, the exactions may be based on future needs, and the fee formula is more closely related to the likely impact of the project. The Boston program was never meant to be anything but a way of implementing social policy. The study notes that it "was charged to investigate how to effect linkage, not whether there should be linkage." Consequently, there is not even a representation that there is "a cause and effect relationship between large-scale development activity and the shortage of affordable housing in the neighborhoods." See Advisory Group REPORT, supra note 39, at 2.

64. Unfortunately, the study did not isolate the impact or tie the fee formula to such impact.

65. 391 Mass. at 426,466 N.E.2d at 1106.

66. Because Boston is not subject to the state zoning law, it appears that it may not rely upon implicit powers under home rule authority. See Emerson College v. City of Boston, 391 Mass. 415 , 462 N.E.2d 1098 (1984); Banquer Realty Co. v. Acting Bldg. Comm 'r, 389 Mass. 565, 571 n.6, 451 N.E.2d 422, 426 n.6 (1983).

67. See Tegeler, supra note 8 , at $680-81,691-92$. 
item like housing, it can then argue that in order to remedy that shortage, linkage is a legitimate and necessary exercise of its police power. It appears, however, that such programs will meet the same resistance that initially confronted impact fees. As a result, municipalities must draft their linkage programs to meet the same legal tests that courts have applied to impact fee programs. The core elements of these tests are clear legislative authorization of linkage, a demonstration that commercial developments do in fact strain the housing market, and a specific correlation between the fee structure and the impact. The municipality must persuade the court that the costs are sufficiently attributable to, and the benefits reach, the development or those persons likely to be drawn to the city because of the development. ${ }^{68}$

\section{III}

\section{Conclusion}

Exactions are now entrenched as a form of municipal financing and land use regulation, and developers must learn to live with them. Given the current financial difficulties of many cities, it is likely that municipalities will attempt to expand still further the circle of exactions. In a world of competing interests, an approach consistent with the rule of law should limit the expanding circle by using the reasonability tests thus far developed by the courts. It is fair for a developer to pay for the socioeconomic costs of his development. The payments must, however, reasonably match the municipal costs incurred because of such development, and the development must receive concrete benefit from the improvements.

A problem arises with certain expansions of the exaction circle, such as Boston's linkage program. It is possible that municipal needs for infrastructure improvements and developer needs to proceed with construction may rupture the delicate balance forged by the case law. Perhaps the best way to assure the preservation of the rule of law in this volatile area is to adhere to the above outlined model of express legislation and specific, detailed findings of fact. This model assures reasonablility by requiring a proportionate balancing of competing interests. Although this model will require developers to pay exactions in certain cases, it is the only assurance there is that, as Justice Holmes noted in an early taking case, "a strong public desire to improve the public condition [will not] warrant achieving the desire by a shorter cut than the constitutional way of paying for the change."69

68. Diamond goes so far as to suggest that the housing funds received in connection with a linkage program should be used "to build housing that exactly [matches] the income profile of office tenants." Diamond, supra note 1 , at 473 . This suggestion, of course, may mean that the housing units constructed pursuant to a linkage program will benefit middle-income urban professionals rather than the poor.

69. Pennsylvania Coal Co. v. Mahon, 260 U.S. 393, 416 (1922). 
